\title{
CHORISTOMAS AND TERATOMAS OF ORAL CAVITY
}

Dr. Sona Baburathinam ${ }^{1}$, Dr. Vidyrani Shyamsundar ${ }^{2}$, Dr. Aravindha Babu. $\mathbf{N}^{3}$, Masthan.K.M.K ${ }^{4}$

${ }^{1}$ Postgraduate, Department of Oral Pathology and Microbiology, Bharath Institute of Higher Education and Research, Sree Balaji Dental College and Hospitals.

${ }^{2}$ Professor, Department of Oral Pathology and Microbiology, Center for Oral Cancer Prevention Awareness and Research, Bharath Institute of Higher Education and Research, Sree Balaji Dental College and Hospitals.

${ }^{3}$ Professor, Department of Oral Pathology and Microbiology, Center for Oral Cancer Prevention Awareness and Research, Bharath Institute of Higher Education and Research, Sree Balaji Dental College and Hospitals.

${ }^{4}$ Professor \& Head of the Department, Department of Oral Pathology and Microbiology, Center for Oral Cancer Prevention Awareness and Research, Bharath Institute of Higher Education and Research, Sree Balaji Dental College And Hospitals.

Article Info: Received 10 May 2019; Accepted 22 June. 2019

DOI: https://doi.org/10.32553/jbpr.v8i3.616

Address for Correspondence: Dr. Sona Baburathinam, Postgraduate, Department of Oral Pathology and Microbiology, Bharath Institute of Higher Education and Research, Sree Balaji Dental College and Hospitals. Tamilnadu, Chennai600100

Conflict of interest statement: No conflict of interest

\section{ABSTRACT:}

A cohesive tumor-like mass consisting of normal cells in an abnormal location constitutes a choristoma, while teratomas are considered as true neoplasms, consisting of tissues derived from all three germ layers. The occurrence of these lesions in the oral cavity is rare. They are considered in the differential diagnosis of reactive and benign lesions that commonly occur in the oral cavity. This article provides an overview of the various choristomas and teratomas that can occur in the oral cavity.

\section{Introduction}

Choristomas are aggregates of histologically normal cells or tissues present in aberrant locations. Teratomas are composed of tissues from all three germ layers that exhibit varying levels of maturity. The non-salivary epithelial choristomas occur commonly in the tongue, while the tongue is an uncommon site for teratomas. Various types of choristomas and teratomas occur in the oral cavity 1.

\section{Choristomas of the oral region:}

Choristomas of the oral region have been classified by Chou et al $^{2}$. The classification was based on the various types of tissue recognized at light microscopic level.

1. Salivary gland choristoma

a. Central

b. Gingival

2. Cartilaginous choristoma
3. Osseous choristoma

4. Lingual thyroid choristoma

5. Lingual sebaceous choristoma

6. Glial choristoma

7. Gastric mucosal choristoma

a. Cystic

b. Solid

Ectopic lymphoid tissue that occurs in the oral cavity is considered a component of lymphoepithelial cyst and is thus excluded. Similarly, oral lesions having respiratory mucosa are regarded as a form of metaplasia and thus excluded $^{3-6}$.

\section{Salivary gland choristoma:}

It is an aberrant salivary gland tissue that presents as a tumor-like mass. Most of them commonly present as an indentation on the mandibular lingual surface or as a pedunculated mass that extends through a perforation in the mandible with a connection to the submandibular or sublingual 
gland ${ }^{7-9}$. They were termed as "static bone cyst", "salivary gland inclusion in the mandible", "aberrant salivary gland defect" ${ }^{10-12}$. Few lesions are located on the attached gingiva and termed "gingival salivary gland choristoma" ${ }^{13,14}$. Lesions are classified as 'central' or 'gingival' depending on their location.

The central salivary gland choristoma occurs as a solid mass of salivary tissue enclaved within the mandible, with no evidence of connection with the submandibular or sublingual glands. They occur in the anterior mandible. They appear as wellcircumscribed radiolucencies with sclerotic borders. The possible origin includes:

a. Mucous metaplasia of the epithelial lining of odontogenic cyst ${ }^{15}$

b. Embryologically entrapped retromolar mucous salivary tissue ${ }^{16}$.

The gingival choristoma occurs as an asymptomatic, solitary mass in the buccal or lingual gingiva with no bone involvement. The first reported case was by Moskow and Baden, $1964{ }^{13}$. The proposed possibilities ${ }^{14,17}$ of origin include:

a. Developmental displacement of minor salivary gland tissue

b. Metaplasia from multipotent gingival epithelium.

\section{Cartilaginous choristoma:}

Masses of differentiated cartilage are reported to occur in the tongue, buccal mucosa and soft palate ${ }^{18-21}$. Microsopically, they are composed of a tumorlike mass of hyaline cartilage surrounded by dense, fibrous connective tissue, suggesting perichondrium, by loose fibrous connective tissue or by myxoid tissue, suggesting primitive mesenchyme. Chondrocytes within the lacunar spaces may be small or large. The cartilage is commonly more mature at the center of the mass compared to the periphery. Cartilaginous choristomas must to be differentiated from extraskeletal chondrosarcomas as the latter have cellular pleomorphism, giant cells and lack welldifferentiated hyaline ${ }^{22}$.

\section{Osseous choristoma:}

It was described by Krolls ${ }^{23}$ et al as a tumor-like mass of normal, mature lamellated bone occurring in the soft tissue of the oral cavity. They are known by other names such as "osteoma mucosae" or "soft tissue osteoma". They commonly arise on the dorsum of the tongue, posteriorly, near the foramen caecum or circumvallate papillae. Other sited include mid-dorsal area of tongue, lingual alveolar mucosa of anterior mandible and buccal vestibule ${ }^{24-27}$. They occur as a sessile or pedunculated mass and are asymptomatic. Microscopically, they contain lamellated vital bone with haversian canals surrounded by dense fibrous tissue. Surface is lined by stratified squamous epithelium. Osteocytes are seen within the lacunae.

\section{Lingual thyroid choristoma:}

It is a tumor-like mass that occur in the midline of the tongue between the foramen caecum and epiglottis. It occurs a $s$ a round or hemispheric, semi-soft or firm mass, often lobulated but covered by intact mucosa. In most cases, the growth would be the only functioning thyroid tissue in the body when determined by thyroid scan techniques. Hypothyroidism is often associated with a unique functional lingual thyroid. Microscopically, embryonic or mature thyroid tissue is seen, with an incomplete or poorly defined capsule. Lymphocytic infiltration is common. When the patient is symptomatic and requires treatment, radioactive iodine 131 or thyroid hormone suppression is done to reduce the size of the glands ${ }^{28-31}$.

\section{Lingual sebaceous choristoma:}

Sebaceous glands occur on the buccal, labial mucosa, retromolar area, gingiva and palate ${ }^{32}$. Occurrence on the tongue is considered ectopic ${ }^{33}$. It occurs on the posterior part of the dorsum of the tongue as a firm, asymptomatic, dome-shaped mass. They appear as small, yellowish aggregates. Microscopically, the lesions consist of lobules of well-differentiated branching sebaceous glands.

\section{Glial choristoma:}

It is a rare occurrence of mature brain tissue within the oral cavity. They are reported to occur on the soft palate, sometimes extending to the hard palate as a raised firm mass. Microscopically they consist of mature central nervous tissue elements. Astrocytes are identified are seen within masses of glial fibers ${ }^{34,35}$.

\section{Gastric mucosal choristoma:}

They occur as a cystic or solid entity. The cystic lesion is lined partly by stratified squamous epithelium and partly by gastric mucosa and rarely by intestinal epithelium. Majority occur on the ventral surface of the tongue. Heterotopic gastric mucosa is thought to arise from misplaced embryonic gastric rests as during 4 weeks of intra- 
uterine life, the undifferentiated primitive stomach lies in the mid-neck region, close to the tongue ${ }^{36}$. Solid lesions occur on the dorsum of the tongue, at the junction of anterior two-third and posterior one-third. They are composed of mucosa identical to that of fundus and body of stomach ${ }^{37}$.

\section{Teratomas of the oral region:}

Teratomas are true neoplasms composed of multiple tissues that are foreign to the site from which they originate ${ }^{38}$. Oral teratomas are extremely rare, with most cases occurring on the tongue. While their histogenesis is still debatable, the most popular theory suggests that they arise from totipotent embryonic tissues that are displaced during ontogeny. There is alteration in cell membrane permeability. The synchronous presence of embryonal, fetal and adult elements is seen ${ }^{39,40}$.

Arnold's classification system ${ }^{39}$ :

1. Dermoid tumors: most common form composed of ectoderm and mesoderm.

2. Teratoid tumors: Poorly differentiated lesions composed of all three germ layers.

3. True teratomas: Histologically identifiable tissue from all three germ layers. They may be solid or cystic.

4. Epignathus: Also known as 'fetus in fetu' or 'parasitic fetus'and contains fetal organs. It is a misnomer and its etymological meaning is 'upon the jaw'.

These tumors are histologically benign with no evidence of malignancy. They should be differentiated from an epidermoid cyst composed of epidermal cells, a dermoid cyst that consists of ectodermal and mesodermal derivatives, a teratoid cyst, that is a poorly differentiated tumor composed of all three germ layers and an epignathus, with presence of developmental fetal organs and limbs. Teratomas commonly tend to be midline lesions, though they clinically present as being prominent on one side. Surgical excision is the treatment of choice.

\section{Conclusion:}

Occurrence of choristomas and teratomas in the oral region, though uncommon, is not rare. They should be considered in the differential diagnosis of the common reactive and benign lesions of the oral cavity. Early and precise microscopic diagnosis aids in surgical excision to avoid discomfort. Recurrences are extremely rare.

\section{References:}

1. Batsakis JG. Nomenclature of developmental tumors. Ann Otol Rhinol Laryngol 1984; 93: 98-9.

2. Chou L, Hansen LS, Daniels TE. Choristomas of the oral cavity. Oral Surg Oral Med Oral Pathol 1991; 72: 584-93.

3. Giunta J, Cataldo E. Lymphoepithelial cysts of the oral mucosa. Oral Surg Oral Med Oral Pathol 1973; 35: 77-84.

4. Weitzner S. Lymphoepithelial (branchial) cyst of the parotid gland. Oral Surg Oral Med Oral Pathol 1973; 35: 85-8.

5. Knapp MJ. Oral tonsils: location, distribution and histology. Oral Surg Oral Med Oral Pathol 1970; 29: 155-61.

6. Buchner A, Hansen LS. Lymphoepithelial cysts of the oral cavity. Oral Surg Oral Med Oral Pathol 1980; 50: 441-9.

7. Slavin MI. Ectopically placed parotid gland in the mandible. Oral Surg Oral Med Oral Pathol 1950; 3: 1372-6

8. Gosney MBE, Giles AD. Atypical mandibular salivary inclusion. Br Dent J 1981; 151: 381-2

9. Gorman JM, O'Brien FV. Salivary inclusion in the mandible: a case report. Br Dent J 1972; 133: 69-70.

10. Palladino VS, Rose SA, Curran T. Salivary gland tissue in the mandible and Stafne's mandibular cyst. J am Dent Assoc 1965; 70: 388-93.

11. Abbas F, Bras J. Intra-osseous salivary gland inclusion of the mandible. Int J Oral Surg 1985; 14: 560-3.

12. Sandy JR, Williams DM. Anterior salivary gland inclusion in the mandible: pathological entity or anatomical variant? Br J Oral Surg 1981: 19: 223-9.

13. Brannon RB, Houston GD, Wampler HW. Gingival salivary gland choristoma. Oral Surg Oral Med Oral Pathol 1986; 85-188.

14. Ide F, Shimura H, Saito I, Umemura S. Gingival salivary gland choristoma: an extremely rare phenomenon. Oral Surg, Oral Med Oral Pathol 1983; 55: 169-72.

15. Alvares $O$, Olech E, Silverglade LB. Lingual and mandibular bone cavity concomitant with a dentigerous cyst: aclinical and histologic report. Oral Surg Oral Med Oral Pathol 1969; 27: 252-6. 
16. Bhaskar SN. Central mucoepidermoid tumors of the mandible. Cancer 1963; 16: 721-6.

17. Bennett JS, Grupe HE. Epithelial adnexal formation in human gingiva. Oral Surg Oral Med Oral Pathol 1967; 23: 789-95.

18. Yoel J, Pundyk C. Chondroma of the tongue. Oral Surg Oral Med Oral Pathol 1965; 20: 57882.

19. Bruce KW, McDonald JR. Chondroma of the tongue. Oral Surg, Oral Med Oral Pathol 1953; 6: 1281-3.

20. Sultani FA, Krolls SO, Heckler FR. Cartilaginous choristoma of buccal mucosa: a case report. $\mathrm{Br}$ J Plas Surg 1983; 36: 395-7.

21. Tohill MJ, Green GJ, Cohen DM. Intraoral osseous and cartilaginous choristoma: report of three cases and review of literature. Oral Surg Oral Med Oral Pathol 1987; 63: 506-10.

22. Forman $\mathrm{G}$. Chondrosarcoma of tongue. $\mathrm{Br} \mathrm{J}$ Oral Surg 1967; 4: 218-21.

23. Krolls So, Jacoway JR, Alexander WN. Osseous choristomas of intraoral soft tissues. Oral Surg Oral Med Oral Pathol 1971; 32: 588-95.

24. Weitzner S. Osseous choristoma of the tongue. South Med J 1986; 79: 69-70.

25. Engel $P$, Cherrick $H$. Extraosseous osteomas of the tongue. J Oral Med 1976; 31: 99-103.

26. Sheridan SM. Osseous choristoma: A report of two cases. Br L Oral Maxillofac Surg !984; 22: 99- 102.

27. Davis GB. Intraoral osseous choristoma: report of a case. J Oral Surg 1980; 38: 144.

28. Sauk JJ Jr. Ectopic lingual thyroid. J Pathol 1970; 102: 230-43.

29. Jones JAH. Lingual thyroid. Br J Oral MAxillofac Surg 1986; 24: 58-62.
30. Katz $A D$, Zager WJ. The lingual thyroid, its diagnosis and treatment. Arch Surg 1971; 102: 582-5.

31. Keen RR, Jordan JE, Miller GA. Lingual thyroid: report of a case. Oral Surg Oral Med Oral Pathol 1971; 31: 627-30.

32. Halperin V, Kolas $S$, jefferis KR, Huddleston So, Robison HBG. The occurrence of fordyce's spots, benign migratory glossitis, median rhomboid glossitisand fissured tongue in 2478 dental patients. Oral Surg Oral Med Oral Pathol 1953; 6: 1072-7.

33. Guiducci AA, Hyman AF. Sebaceous glands in the tongue. Arch Dermatol 1954; 70: 349-54.

34. Shapiro MJ, Mix BS. Heterotopic brain tissue in the palate. Arch Otolaryngol 11968; 87: 96100.

35. Garcia MG, Avila CG, Arranz JSL, Garcia JG. Heterotopic brain tissue in the oral cavity. Oral Surg Oral Med Oral Pathol 1988; 66: 71-3.

36. Wolff $M$, Rankom RM. Heterotopic gastric epithelium in the head and neck region. Ann Plast Surg 1980; 4: 53-64.

37. Gruskin P, Landolfe FR. Heterotopic gastric mucosa of the tongue. Arch Pathol 1972; 94: 184-6.

38. Lopes MA, Pereira CM, Perez DE, Vargas PA, de Almeida OP. Benign teratoma of the buccal mucosa in a 9-year old girl: Report of a case and review of literature. Oral Surg Oral Med Oral Pathol Oral Radiol Endod 2005; 100(5): 598-602.

39. Gupta M, Chaudhary N. Teratoma tongue: Case report and review of literature. Indian J Otolaryngol Head Neck Surg 2007; 59: 160-2.

40. Ashley DJ. Origin of teratomas. Cancer 1973; 32: 390-4. 